\title{
Bank Debt Reduction Announcements and Negative Signaling
}

\section{Robert M. Hull and Richard Moellenberndt}

Robert M. Hull is an Assistant Professor of Finances. Richard Moellenberndt is a Professor of Accounting. Both are at Washburn University School of Business."
We examine 242 NYSE/AMEX and OTC common stock offerings that reduce bank debt and 254 that retire nonbank debt. We discover that bank debt reductions are associated with negative announcement period stock returns that are more than twice the magnitude of the negative returns found for nonbank debt reductions. The significant difference in returns indicate bank debt reductions transmits negative information beyond that previously cited in the stock offering literature. Regression tests show that the explanatory variable representing bank debt signaling models best explains stock returns.

Bankers are parties to information about a firm's financial condition through their special relationship as lenders. This premise is the basis for the predictions of bank debt signaling models, which posit that bank debt issuance announcements convey positive news about a firm. Empirical research on debt offering announcements that raise cash for multi-corporate purposes supports this claim. The research documents statistically significant positive stock price reactions to bank debt announcements and negative reactions to nonbank debt announcements.

If bank debt issuance announcements signal more favorable news than nonbank debt announcements, it follows that bank debt reduction announcements should signal more negative news than nonbank debt reduction announcements. Market participants will view bank debt reduction announcements as the result of decisions made by bankers acting upon unfavorable inside information.

Our study extends prior research on equity offerings that reduce debt. We analyze 242 stock offering announcements that reduce bank debt, and 254 announcements that retire nonbank debt. Consistent with the predictions of bank debt signaling models, returns for bank debt reductions are more negative than returns for nonbank debt reductions, and the differences in returns are statistically significant.

\section{Competing Capital Structure Models}

Event study research finds a significant negative stock valuation effect for equity-for-debt transactions such as exchange offers, private swaps, and stock offerings that raise cash to reduce debt. These findings are consistent with capital structure models that predict negative tax, agency, and signaling effects.

Tax models, rooted in Modigliani and Miller (1963), hypothesize negative stock price behavior from lost tax shields when firms undergo stock-for-debt transactions. Agency models that deal with risk shifting, such as the intrasecurity wealth transfer model of Galai and Masulis (1976), also hypothesize negative stock price behavior. The cash flow payments to debtholders become less risky, while payments to stockholders become more risky. This causes wealth transfers from stockholders to debtholders.

Asymmetrical information models (e.g., Leland and Pyle (1977) and Ross (1977)) predict that stock-for-debt transactions signal negative news. Leland and Pyle connect negative signaling to decreases in the percentage of inside ownership caused when insiders do not participate in the stock offering. ${ }^{1}$ Ross links the negative signaling to the reduction in debt. Decreases in debt convey negative information about a firm's ability to service current debt levels.

Signaling models that stress the role of bankers as insiders (Fama (1985; Kane and Malkiel (1965; and Bernanke (1983)) argue that firms announcing bank debt agreements convey positive news. That is, bankers would not approve or extend a loan if inside information acquired in the lending process were negative. It follows that the market will suspect that bank debt reductions are prompted by negative inside information. Thus, announcements of bank debt reduction should result in greater negative news than

\footnotetext{
Robert Hull is corresponding author and can be contacted at rob.hull@washburn.edu. The authors are grateful to George Pinches, Robert Kerchner, Doug Emery, John Finnerty, and the anonymous reviewers for their comments and suggestions.

${ }^{1}$ Since insiders can include managers a negative prediction is also consistent with agency models based on Jensen and Meckling (1976). As managers reduce their ownership, they are less likely to make wealth-maximizing decisions on behalf of stockholders For stock for debt transactions, however, the negative agency prediction holds only if any positive agency effect from reducing the conflict between debtholders and stockholders does not offset or outweigh it. In addition to tax, agency, and signaling considerations, other models consistent with negative price behavior (but less frequently cited) include corporate control, issuance expenses, and price pressure models.
} 
Bank Debt Reduction Announcements and Negative Signaling / FM (1994), pp. 21-30 / Hull \& Moellenberndt

announcements of nonbank debt reduction. Nonbank loans (including private nonbank debt) are not normally subject to periodic review and termination. Therefore they should be free from negative signaling effects associated with insiders who are lenders.

\section{Prior Empirical Findings}

In this section, we review the empirical findings for stock offering and bank loan announcements. While prior research finds that bank loan announcements have different announcement period returns than nonbank debt announcements, studies of stock for debt transactions have not examined if bank debt reductions cause different announcement period returns than nonbank debt reductions.

\section{A. Stock Offering Findings}

Stock offerings can be classified into two general categories: "cash" and "noncash". The cash category involves stock issues that raise cash for debt reduction and other corporate purposes. These other purposes include capital expenditures, working capital increases, and general corporate requirements. The noncash category involves equity offerings where the new stock is traded for outstanding senior securities.

Cash offering studies (Asquith and Mullins, 1986; Masulis and Korwar, 1986; Mikkelson and Partch, 1983) find negative announcement period stock returns averaging over $-3.0 \%$. In general, cash offering studies indicate that the intended use of the cash proceeds has no obvious impact on returns. For example, Masulis and Korwar (1986) report a two-day return of -3.84\% when the proceeds are used for debt reduction $(n=55) ;-3.65 \%$ when used for capital expenditures $(n=63)$; and, $-2.52 \%$ when used for mixed purposes $(\mathrm{n}=55)$.

Studies of noncash offerings include exchange offers (Masulis, 1980; Masulis, 1983; Pinegar and Lease, 1986) and private swaps (Finnerty, 1985; Peavy and Scott, 1985; Rogers and Owers, 1985). More recent work (Copeland and Lee, 1991; Cornett and Travlos, 1989) is on both exchange offers and swaps. The mean announcement period stock returns for noncash transactions range from $-9.91 \%$, as shown by Masulis (1983) for exchange offers of common stock for nonconvertible debt ( $\mathrm{n}=9$ ), to $-0.83 \%$, as found by Peavy and Scott (1985) for swaps of common stock for debt $(\mathrm{n}=72)$.

\section{B. Bank Debt Findings}

Research shows that banks play a unique role as transmitters of information in the capital markets. For example, Mikkelson and Partch (1986) find a statistically significant $0.89 \%$ mean announcement period stock return upon disclosure of bank loan agreements $(n=124)$, compared to a negative $-0.57 \%$ return for private placements of debt $(n=57)$. James $(1987)$ reports a significant $1.92 \%$ return for bank loan agreements $(n=80)$, in contrast to negative returns of $-0.11 \%$ for public straight debt offerings $(n=90)$ and $-0.91 \%$ for private placements $(n=37)$. When the announced purpose is to repay bank loans, the stock return is $-1.63 \%$ for public debt offerings $(\mathrm{n}=12)$ and $-2.07 \%$ for private placements $(\mathrm{n}=18)$.

Lummer and McConnell (1989) discover that the positive return seen in the case of bank loan announcements is not explained by actions on new bank loans or outstanding bank loans that are unfavorably structured, but by bank loans that receive favorable or mixed revision. They find positive returns of $0.87 \%$ for favorable revisions $(n=259)$ and $3.98 \%$ for mixed revisions $(n=76)$. For mixed revisions, the return is $4.82 \%$ when there is prior negative news $(n=50)$ concerning the loan (published in The Wall Street Journal) for the year prior to the revision announcement. The return is $2.35 \%$ when there is no prior negative news $(n=26)$.

The results of these studies suggest that stock issues that reduce bank debt obligations should experience more negative returns than stock issues that retire nonbank debt. This should be true especially if there is either nonnegative news or no news about the firm's outstanding bank debt prior to the announcement.

\section{Data and Methodology}

The first part of this section describes our stock offering sample. The sample is much larger than previously examined by similar studies and spans nearly two decades. Next, we discuss the methodology for calculating announcement period returns, and detail the primary tests that are performed.

\section{A. Data}

The primary sources of common stock offering announcements for the study are the Investment Dealers' Digest and The Wall Street Journal. Besides these two sources, the sources for the descriptive data are Compustat Annual Files, Moody's Industrial Manual, and the CRSP NYSE/AMEX and CRSP OTC daily prices and returns files. The data covers the years between 1970 and 1988.

The sample consists of 496 stock offerings that meet five criteria:

1. Each must be a common stock offering in which the stated purpose is to reduce some form of debt that is not convertible into equity.

2. Each must indicate whether the debt being retired is bank debt or nonbank debt.

3. Each must not be identified as a utility.

4. Each must be listed on the CRSP NYSE/AMEX return file or the CRSP OTC return file, and have sufficient trading data to calculate an announcement period cumulative abnormal return.

5. The percentage change in outstanding common stock must lie between $0.5 \%$ and $100 \%$.

The 496 observations include 242 firms that retire bank debt and 254 that reduce nonbank debt. The sample also includes 117 that are listed on the CRSP OTC return file and 379 that are listed on the CRSP NYSE/AMEX return file. Of the 496 observations, there are 67 combination offerings (primary component plus registered secondary offering), and 429 primary offerings that are not 
Bank Debt Reduction Announcements and Negative Signaling / FM (1994), pp. 21-30 / Hull \& Moellenberndt

accompanied by a secondary offering. An observation is classified as a combination offering if the primary portion of the offering is accompanied by a secondary offering that is at least 10 percent of the total offering.

EXHIBIT 1. Descriptive Data for 496 Common Stock Offerings that Reduce Bank Debt and Nonbank Debt, 1970-1988

\begin{tabular}{|c|c|c|c|c|}
\hline $\begin{array}{l}\text { Descriptive } \\
\text { Data }\end{array}$ & $\begin{array}{l}\text { Bank Debt } \\
\text { Reduction } \\
\text { Portfolio } \\
\quad(n=242)\end{array}$ & $\begin{array}{l}\frac{\text { Nonbank }}{\text { Total }} \\
\text { Portfolio } \\
(n=254)\end{array}$ & $\begin{array}{c}\text { Debt } \text { Reduction } \\
\text { Swap } \\
\text { Portfolio } \\
(n=194)\end{array}$ & $\begin{array}{c}\text { Portfolios } \\
\text { Nonswap } \\
\text { Portfolio } \\
(n=60)\end{array}$ \\
\hline \multicolumn{5}{|l|}{ Time Period $^{a}$} \\
\hline $1970-1972$ & $30 \quad(12 \%)$ & $6 \quad(2 \%)$ & $\odot \quad(\odot \%)$ & $6(10 \%)$ \\
\hline $1973-1975$ & $18 \quad(7 \%)$ & $5 \quad(2 \%)$ & $\odot \quad(\odot \%)$ & $5 \quad(8 \%)$ \\
\hline $1976-1978$ & 27 (11\%) & $7 \quad(3 \%)$ & $\odot \quad(\odot \%)$ & 7 (12\%) \\
\hline $1979-1981$ & $9 \odot \quad(37 \%)$ & 39 (15\%) & $29(15 \%)$ & $10(17 \%)$ \\
\hline $1982-1984$ & 57 (24\%) & $186(73 \%)$ & $165(85 \%)$ & 21 (35\%) \\
\hline $1985-1988$ & $20 \quad(8 \%)$ & $11(4 \%)$ & $\odot \quad(\odot \%)$ & 11 (18\%) \\
\hline \multicolumn{5}{|l|}{ Selected Variable } \\
\hline $\begin{array}{l}\text { Firm Value } \\
(\mathrm{M}=\text { million })\end{array}$ & $\begin{array}{r}\text { \$569M } \\
(\$ 169 M)\end{array}$ & $\begin{array}{r}\$ 2,735 \mathrm{M} \\
(\$ 1,410 \mathrm{M})\end{array}$ & $\begin{array}{r}\$ 3,282 \mathrm{M} \\
(\$ 1,753 \mathrm{M})\end{array}$ & $\begin{array}{r}\text { \$965M } \\
(\$ 269 M)\end{array}$ \\
\hline $\begin{array}{l}\text { Common Stock value } \\
\qquad(M=\text { million })\end{array}$ & $\begin{array}{l}\$ 334 \mathrm{M} \\
(\$ 98 \mathrm{M})\end{array}$ & $\begin{array}{r}\$ 1,269 \mathrm{M} \\
(\$ 735 \mathrm{M})\end{array}$ & $\begin{array}{r}\$ 1,496 \mathrm{M} \\
(\$ 870 \mathrm{M})\end{array}$ & $\begin{array}{r}\$ 536 \mathrm{M} \\
(\$ 227 \mathrm{M})\end{array}$ \\
\hline $\begin{array}{l}\text { Expected Proceeds } \\
(M=\text { million })\end{array}$ & $\begin{array}{c}\$ 37 \mathrm{M} \\
(\$ 17 \mathrm{M})\end{array}$ & $\begin{array}{r}\$ 34 M \\
(\$ 19 M)\end{array}$ & $\begin{array}{r}\$ 30 M \\
(\$ 19 M)\end{array}$ & $\begin{array}{r}\$ 49 M \\
(\$ 17 M)\end{array}$ \\
\hline $\begin{array}{l}\text { Relative Size of } f \\
\text { the offering }\end{array}$ & $\begin{array}{r}19.2 \% \\
(16.4 \%)\end{array}$ & $\begin{array}{r}6.6 \% \\
(3.2 \%)\end{array}$ & $\begin{array}{r}3.6 \% \\
(2.3 \%)\end{array}$ & $\begin{array}{r}16.4 \% \\
(11.4 \%)\end{array}$ \\
\hline $\begin{array}{l}\text { Relative Size of } \mathbf{g} \\
\text { the Leverage Change }\end{array}$ & $\begin{array}{l}-10.9 \% \\
(-8.7 \%)\end{array}$ & $\begin{array}{r}-4.3 \% \\
(-1.9 \%)\end{array}$ & $\begin{array}{r}-2.6 \% \\
(-1.4 \%)\end{array}$ & $\begin{array}{r}-9.7 \% \\
(-7.0 \%)\end{array}$ \\
\hline
\end{tabular}

${ }^{a}$ Number of observations per time period with percent of the portfolio for that period given in parentheses.

b Means are reported, with medians in parentheses. Statistics are obtained from the sources closest (yet prior) to announcement.

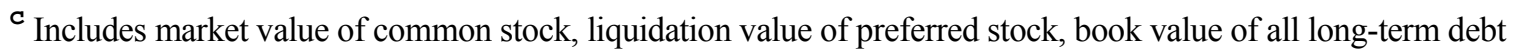
obligations (including capitalized leases), and current liabilities.

d Price the day before the announcement times the outstanding common shares last reported prior to the announcement.

e Price the day before the announcement times the number of new or primary common shares.

$\mathbf{f}$ Percentage change in common stock as measured by the planned new (primary) common shares divided by outstanding common shares.

${ }^{\mathbf{g}}$ Expected book value of retired debt divided by firm value.

The sample consists of 287 cash offerings and 209 noncash offerings. The 209 noncash offerings include 194 private swaps and 15 exchange offers. All noncash offerings involve the retirement of nonbank debt. None of the noncash offerings are associated with a combination offering.

Of the 496 observations, there are 56 where other firm-specific announcements occur during event days -3 through +3 . There are 22 cash offering observations for which sources differ as to whether the entire proceeds is to be used for debt reduction. There are 15 noncash offering observations where cash from the current asset account is used to help reduce debt. As exclusion of these 93 $(56+22+15)$ observations does not alter the reported findings, all are retained for the analysis.

Exhibit 1 reports descriptive data for the bank debt reduction and nonbank debt reduction portfolios. Data for the latter portfolio is also presented for swaps $(\mathrm{n}=194)$ and nonswaps $(\mathrm{n}=60)$. Swaps are clustered in a four-year period and tend to have been issued by 
Bank Debt Reduction Announcements and Negative Signaling / FM (1994), pp. 21-30 / Hull \& Moellenberndt

larger firms that undergo smaller relative size changes. ${ }^{2}$ The exhibit shows that mean values for the two relative size variables are similar, when comparing bank debt reductions with the nonbank debt reductions that are not swaps.

\section{EXHIBIT 2. Announcement Period Return Results for Event Days -5 through +5 for Five Portfolios Involving Equity Issues that Reduce Bank Debt and Nonbank Debt, 1970-1988}

The exhibit reports for each event day (or event period) the abnormal return (or cumulative abnormal return) for the portfolio under consideration. The first row reports $t$ statistics (when testing the null hypothesis that the portfolio return is equal to zero). Beneath each portfolio return in parenthesis is its percent that is positive used to render binomial $z$ statistics (when testing the null hypothesis that the percent is equal to 50 percent). Significance levels are indicated as follows: * denotes significance at the 0.01 level; ** denotes significance at the 0.05 level.

\begin{tabular}{|c|c|c|c|c|c|}
\hline $\begin{array}{l}\text { Event } \\
\text { Days }\end{array}$ & $\begin{array}{c}\text { Total } \\
\text { Sample } \\
(n=496)\end{array}$ & $\begin{array}{c}\text { Bank Debt } \\
\text { Reduction } \\
\text { Portfolio } \\
\quad(n=242)\end{array}$ & $\begin{array}{c}\text { Nonbank Debt } \\
\text { Total } \\
\text { Portfolio } \\
(n=254)\end{array}$ & $\begin{array}{l}\text { Reduction } \\
\text { Swap } \\
\text { Portfolio } \\
(n=194)\end{array}$ & $\begin{array}{l}\text { Portfolios } \\
\text { Nonswap } \\
\text { Portfolio } \\
(n=60)\end{array}$ \\
\hline-5 & $\begin{array}{c}-0.17 \% \\
\left(44 \%^{*}\right)\end{array}$ & $\begin{array}{c}-0.48 \%^{* *} \\
\left(39 \%^{*}\right)\end{array}$ & $\begin{array}{l}0.13 \% \\
(49 \%)\end{array}$ & $\begin{array}{l}0.25 \% \\
(49 \%)\end{array}$ & $\begin{array}{c}-0.29 \% \\
(47 \%)\end{array}$ \\
\hline-4 & $\begin{array}{l}\odot .09 \% \\
(49 \%)\end{array}$ & $\begin{array}{l}-\Theta . \odot 2 \% \\
\left(44 \%^{* *}\right)\end{array}$ & $\begin{array}{l}0.20 \% \\
(55 \%)\end{array}$ & $\begin{array}{l}0.26 \% \\
\left(57 \%^{* *}\right)\end{array}$ & $\begin{array}{c}-0.00 \% \\
(47 \%)\end{array}$ \\
\hline-3 & $\begin{array}{l}0.03 \% \\
(51 \%)\end{array}$ & $\begin{array}{l}0.11 \% \\
(49 \%)\end{array}$ & $\begin{array}{c}-0.04 \% \\
(53 \%)\end{array}$ & $\begin{array}{c}-\odot .04 \% \\
(54 \%)\end{array}$ & $\begin{array}{c}-0.04 \% \\
(48 \%)\end{array}$ \\
\hline-2 & $\begin{array}{c}-0.11 \% \\
\left(43 \%^{*}\right)\end{array}$ & $\begin{array}{c}-0.34 \%^{* *} \\
\left(38 \%^{*}\right)\end{array}$ & $\begin{array}{l}0.11 \% \\
(48 \%)\end{array}$ & $\begin{array}{l}0.14 \% \\
(48 \%)\end{array}$ & $\begin{array}{r}-0.01 \% \\
(48 \%)\end{array}$ \\
\hline-1 & $\begin{array}{r}-0.48 \%^{*} \\
\left(42 \%^{*}\right)\end{array}$ & $\begin{array}{r}-0.65 \%^{*} \\
\left(39 \%^{*}\right)\end{array}$ & $\begin{array}{r}-0.31 \%^{* *} \\
\left(44 \%^{* *}\right)\end{array}$ & $\begin{array}{c}-0.24 \% * * \\
(46 \%)\end{array}$ & $\begin{array}{l}-0.54 \% \\
\left(38 \%^{* *}\right)\end{array}$ \\
\hline$\odot$ & $\begin{array}{r}-1.68 \%^{*} \\
\left(26 \%^{*}\right)\end{array}$ & $\begin{array}{r}-2.37 \%^{*} \\
\left(23 \%^{*}\right)\end{array}$ & $\begin{array}{c}-1.01 \%^{*} \\
\left(28 \%^{*}\right)\end{array}$ & $\begin{array}{r}-1.00 \% * \\
\left(29 \%^{*}\right)\end{array}$ & $\begin{array}{c}-1.04 \% * * \\
\left(23 \%^{*}\right)\end{array}$ \\
\hline+1 & $\begin{array}{r}-0.66 \%^{*} \\
\left(38 \%^{*}\right)\end{array}$ & $\begin{array}{r}-0.78 \%^{*} \\
\left(38 \%^{*}\right)\end{array}$ & $\begin{array}{r}-0.54 \%^{*} \\
\left(38 \%^{*}\right)\end{array}$ & $\begin{array}{r}-0.56 \%^{*} \\
\left(37 \%^{*}\right)\end{array}$ & $\begin{array}{c}-0.48 \% \\
(43 \%)\end{array}$ \\
\hline+2 & $\begin{array}{c}-0.21 \% \\
\left(44 \%^{*}\right)\end{array}$ & $\begin{array}{r}-0.27 \%^{*} \\
\left(40 \%^{*}\right)\end{array}$ & $\begin{array}{c}-0.15 \% \\
(47 \%)\end{array}$ & $\begin{array}{c}-0.13 \% \\
(50 \%)\end{array}$ & $\begin{array}{c}-0.20 \% \\
\left(37 \%^{* *}\right)\end{array}$ \\
\hline+3 & $\begin{array}{l}\odot .0 \odot \% \\
(48 \%)\end{array}$ & $\begin{array}{l}0.10 \% \\
(47 \%)\end{array}$ & $\begin{array}{c}-0.09 \% \\
(49 \%)\end{array}$ & $\begin{array}{c}-0.04 \% \\
(49 \%)\end{array}$ & $\begin{array}{c}-0.27 \% \\
(52 \%)\end{array}$ \\
\hline+4 & $\begin{array}{l}0.15 \% \\
(50 \%)\end{array}$ & $\begin{array}{l}0.19 \% \\
(51 \%)\end{array}$ & $\begin{array}{l}0.11 \% \\
(49 \%)\end{array}$ & $\begin{array}{l}0.07 \% \\
(49 \%)\end{array}$ & $\begin{array}{l}0.26 \% \\
(52 \%)\end{array}$ \\
\hline+5 & $\begin{array}{r}-0.01 \% \\
(47 \%)\end{array}$ & $\begin{array}{c}-0.07 \% \\
(46 \%)\end{array}$ & $\begin{array}{l}\odot .05 \% \\
(48 \%)\end{array}$ & $\begin{array}{l}\odot .06 \% \\
(50 \%)\end{array}$ & $\begin{array}{l}\odot .02 \% \\
(43 \%)\end{array}$ \\
\hline$-1,0,+1$ & $-2.82 \%^{*}$ & $-3.80 \% *$ & $-1.86 \% *$ & $-1.80 \%$ * & $-2.06 \% *$ \\
\hline-5 to +5 & $\begin{array}{r}\left(26 \%^{*}\right) \\
-3.05 \%^{*} \\
\left(32 \%^{*}\right)\end{array}$ & $\begin{array}{r}\left(21 \%^{*}\right) \\
-4.58 \%^{*} \\
\left(26 \%^{*}\right)\end{array}$ & $\begin{array}{r}\left(32 \%^{*}\right) \\
-1.55 \%^{*} \\
\left(37 \%^{*}\right)\end{array}$ & $\begin{array}{r}\left(32 \%^{*}\right) \\
-1.23 \%^{*} \\
\left(40 \%^{*}\right)\end{array}$ & $\begin{array}{c}-2.59 \% * * \\
(27 \% *)\end{array}$ \\
\hline
\end{tabular}

\section{B. Methodology and Primary Statistical Tests}

The ordinary least squares (OLS) market model procedure described by Brown and Warner (1985) is used to test the hypothesis that a sample's event period abnormal return (AR), or cumulative abnormal return (CAR), is equal to zero. The reported AR and CAR results employ Scholes and Williams (1977) alphas and betas that are calculated using the value-weighted CRSP OTC and CRSP

\footnotetext{
${ }^{2}$ As detailed by Hand (1989), private swaps are clustered in a four-year period because they were initiated to take advantage of favorable tax rules that applied until June 1984.
} 
Bank Debt Reduction Announcements and Negative Signaling / FM (1994), pp. 21-30 / Hull \& Moellenberndt

NYSE/AMEX indices for OTC and NYSE/AMEX firms. An estimation period of days +41 to +240 after the announcement date (event day 0 ) is used. ${ }^{3}$

To test the null hypothesis that ARs and CARs for bank debt reductions are less negative than or equal to those for nonbank debt reductions, we compute standard parametric one-tailed $t$ statistics for comparing the equality of the means of two nonpaired samples. The research hypothesis is that the bank debt reduction portfolio will have a greater negative AR or CAR. Rejection of the null hypothesis (at the 0.05 significance level) offers support for bank debt signaling models. Variances are assumed unequal if $F$ values support rejection of the hypothesis that portfolio variances are equal. Nonparametric Wilcoxon rank-sum $z$ statistics are also reported.

For cross-sectional regression tests, $t$ statistics, $F$ values, and adjusted $r$-square values are calculated. One-tailed $t$ statistics are figured for independent variables. This is because each variable is associated with a capital structure model that has a definite prediction concerning the sign of its coefficient.

\section{Event Study Results}

In this section, we present our event study results. We show that stock offerings that reduce bank debt have greater negative announcement period returns than stock offerings that retire nonbank debt. The differences are statistical significant and support bank debt signaling models that predict greater negative returns for bank debt announcements.

\section{A. Daily Abnormal Return Results}

Exhibit 2 reports AR results for event days between day -5 and day +5 and CAR results for a three-day event period $(-1,0$, and $+1)$ and for an eleven-day $(-5$ through +5$)$ event period. Results are given for the total sample of common stock offerings, and the four portfolios described in Exhibit 1. The AR for the total sample is statistically significant at the 0.01 level for the $t$ and $z$ statistics for event days $-1,0$, and +1 . The CAR for these three days of $-2.82 \%$ is similar to the $-3.05 \%$ CAR for the eleven days between -5 and +5 .

The bank debt reduction portfolio column reveals that the negative AR for the total sample is due largely to the portfolio in which bank debt is reduced. This portfolio has a $-4.58 \%$ eleven-day CAR compared to $-1.55 \%$ for the nonbank debt reduction portfolio. Close to half of the $-3.03 \%$ eleven-day difference between portfolios occurs on event day 0 . Event days $-1,0$, and +1 collectively experience about two-thirds of the difference.

The last two columns report the results when the nonbank debt reduction portfolio is partitioned into swaps $(\mathrm{n}=194)$ and nonswaps $(n=60)$. Excluding the superior abnormal returns found for private swaps for event days -5 and -4 , both portfolios have similar ARs.

The results given in Exhibit 2 are consistent with bank debt signaling models that predict greater negative returns for bank debt reductions. Also, the greater negative ARs for bank debt reductions do not depend upon the inclusion of swaps. Furthermore, AR differences between bank debt and nonbank debt reductions do not appear to be contingent upon the relative sizes of the offering or the leverage change. This is because (as seen in Exhibit 1) similar relative size values are found for the bank debt reduction portfolio and the nonbank debt reduction portfolio that consists of nonswaps. As reported in Exhibit 2, the AR differences between these two portfolios still exist.

\section{B. Bank Debt Versus Nonbank Debt Statistical Results}

Exhibit 3 records parametric and nonparametric statistical results when we compare event period returns between the bank debt portfolio and the three nonbank debt reduction portfolios. The five rows report results for event periods ranging from one day to eleven days. All results are at least significant at the 0.05 level for each of the three comparisons.

Results reported in Exhibit 3 are unchanged when tests are conducted that exclude either combination offerings or firms listed on the CRSP OTC file. Because bank debt reductions occur in firms that are smaller in size, tests were also performed on a portfolio excluding that half of the bank debt reduction portfolio that has the smallest size. General results remain unchanged.

The significant results reported in Exhibit 3 would not be totally meaningful (in terms of a manager being able to choose between a bank debt and nonbank debt reduction) if firms in the bank debt reduction portfolio do not have nonbank debt that can be retired. We therefore repeat tests deleting the 36 instances where the amount of outstanding long-term debt was less than the amount of bank debt being retired. The results for these tests are virtually identical to those reported in Exhibit 3.

Tests were duplicated with deletion of 14 additional observations where the amount of short-term debt is greater than that for long-term debt. These additional deletions further insure that firms in the bank debt reduction portfolio have an ample supply of nonbank debt that could be reduced. As before, the results are similar to those given in Exhibit 3.

Finally, tests delete the 50 bank debt reductions just described and 64 nonbank debt reductions where the amount of outstanding short-term debt is less than the amount of the nonbank debt being retired. The purpose of the additional 64 deletions is to eliminate observations where a bank debt reduction may not be a feasible alternative. The results are once again unchanged.

Despite the support for bank debt signaling models, there is the question of why nearly one-quarter of the bank debt reductions have positive CARs. Consistent with the findings of Lummer and McConnell (1989), an argument could be made that negative CARs are more likely to be found for announcements where prior news indicates that bankers plan to renew the loan agreement or they are

\footnotetext{
${ }^{3}$ A post-announcement estimation period that begins on day +41 will start after most of the announcements are completed since it typically takes four weeks before the stock is actually offered. Similar ARs and CARs are found using pre-announcement estimation periods, standard OLS alphas and betas, the equally-weighted indices, and other event period models.
} 
Bank Debt Reduction Announcements and Negative Signaling / FM (1994), pp. 21-30 / Hull \& Moellenberndt

uncertain about renewal. An examination of The Wall Street Journal for the year prior to the issuance announcements finds virtually no articles pertaining to plans to reduce bank debt.

\section{EXHIBIT 3. Event Period Return Results Comparing Common Stock Offerings that Reduce Bank Debt with Common Stock Offerings that Reduce Nonbank Debt, 1970-1988}

The first row reports (for each event period) the difference in AR or CAR means between the bank debt and nonbank debt reduction portfolios being compared. The second row reports the one-tailed parametric $t$ statistic (when testing the null hypothesis that ARs or CARs for bank debt reductions are less negative than or equal to those for nonbank debt reductions) followed by the degrees of freedom. The third row reports (in each parenthesis) the $z$ statistic for the one-tailed nonparametric Wilcoxon test. Significance levels are indicated as follows: * denotes significance at the 0.01 level; ** denotes significance at the 0.05 level.

\begin{tabular}{|c|c|c|c|}
\hline Event Period & Bank Debt & Versus Nonbank Debt & Reduction Tests \\
\hline$\odot$ & $\begin{array}{c}1.36 \%^{\mathrm{a}} \\
5.11^{*} ; 428 \\
\left(4.96^{*}\right)\end{array}$ & $\begin{array}{c}1.37 \%^{\mathbf{b}} \\
5.28^{*} ; 391 \\
\left(5.07^{*}\right)\end{array}$ & $\begin{array}{c}1.33 \%^{c} \\
2.66^{*} ; 301 \\
\left(2.13^{* *}\right)\end{array}$ \\
\hline $0,+1$ & $\begin{array}{c}1.60 \% \\
4.63^{*} ; 446 \\
\left(5.03^{*}\right)\end{array}$ & $\begin{array}{l}1.59 \% \\
4.45^{*} ; 430 \\
\left(4.79^{*}\right)\end{array}$ & $\begin{array}{c}1.63 \% \\
2.99^{*} ; 106 \\
\left(2.91^{\star}\right)\end{array}$ \\
\hline$-1,0,+1$ & $\begin{array}{c}1.94 \% \\
4.68^{\star} ; 476 \\
\left(4.78^{*}\right)\end{array}$ & $\begin{array}{c}2.00 \% \\
4.64^{*} ; 434 \\
\left(4.76^{*}\right)\end{array}$ & $\begin{array}{c}1.74 \% \\
2.45^{*} ; 301 \\
\left(2.29^{*}\right)\end{array}$ \\
\hline-2 to +2 & $\begin{array}{l}2.51 \% \\
4.94^{*} ; 461 \\
\left(4.67^{*}\right)\end{array}$ & $\begin{array}{l}2.62 \% \\
5.00^{*} ; 433 \\
\left(4.78^{*}\right)\end{array}$ & $\begin{array}{c}2.14 \% \\
2.42^{*} ; 301 \\
\left(1.97^{* *}\right)\end{array}$ \\
\hline-5 to +5 & $\begin{array}{l}3.03 \% \\
4.62^{*} ; 460 \\
\left(4.86^{*}\right)\end{array}$ & $\begin{array}{l}3.35 \% \\
5.02^{*} ; 430 \\
\left(5.05^{*}\right)\end{array}$ & $\begin{array}{l}1.99 \% \\
1.71^{* *} ; 301 \\
\left(1.90^{* *}\right)\end{array}$ \\
\hline \multicolumn{4}{|c|}{$\begin{array}{l}\text { a } \text { Reports the results comparing the bank debt reductions }(\mathrm{n}=242) \text { with all of the nonbank debt reductions }(\mathrm{n}=254) \\
\mathbf{b} \text { Reports the results comparing the bank debt reductions }(\mathrm{n}=242) \text { with the nonbank debt reductions that are swaps } \\
(\mathrm{n}=194) \text {. } \\
\mathrm{c}_{\text {Reports results comparing the bank debt reductions ( } \mathrm{n}=242) \text { with the nonbank debt reductions that are not swaps }} \\
(\mathrm{n}=60) .\end{array}$} \\
\hline
\end{tabular}

Nor is any convincing evidence found to link the sign of an observation's CAR with a deteriorating financial condition. For example, no relationship between a CAR's sign and its price behavior for up to 220 days prior to its announcement date could be established. Examination of a number of debt management ratios also reveals no relationship between these ratios and the sign of the CAR.

\section{Regression Results}

This section offers a regression model to explain announcement period returns for stock offerings that reduce bank debt and nonbank debt. We show that valuation effects attributed to bank debt signaling is a dominant effect. Less significant support is found for valuation effects predicted by competing models.

\section{A. Explanatory Variables}

A series of cross-sectional regression tests are conducted to explain differences in three-day CARs between firms offering common stock to reduce bank debt and nonbank debt. The seven independent variables for which results are reported are described below. Some variables are unique to this study; others are similar to those used in prior research (Asquith and Mullins, 1986; Cornett and Travlos, 1989; Finnerty, 1985; Masulis and Korwar, 1986).

SHR represents the change in inside ownership proportions as measured by the number of planned new (primary) common shares divided by total outstanding common shares. A negative coefficient for SHR is hypothesized by the Leland and Pyle (1977) signaling 
Bank Debt Reduction Announcements and Negative Signaling / FM (1994), pp. 21-30 / Hull \& Moellenberndt

model. Higher values for SHR are expected to be associated with greater decreases in ownership proportions. The latter expectation is consistent with findings documenting a positive relationship between changes in inside ownership proportions and the direction of the leverage change (Copeland and Lee, 1991; Karpoff and Lee, 1991).

LEV represents the offering-induced leverage change as measured by the expected book value of retired debt divided by firm value. (Firm value is defined in Exhibit 1). LEV values are assigned negative values to express the negative change in the debt level. Debt-based models such as the Modigliani and Miller (1963) tax model and the Ross (1977) debt level signaling model predict a positive coefficient for LEV.

$\mathrm{CE} 1$ represents the firm's market-adjusted stock performance prior to the event period as measured by the cumulative excess return over the 200-day period from -220 to -21. It is calculated by adjusting stock returns for market returns given by the value-weighted CRSP NYSE/AMEX market index for NYSE/AMEX firms and CRSP OTC market index for OTC firms. A negative coefficient is consistent with the debt level signaling model of Ross (1977). To replace debt at a time when equity value is high would be unexpected and construed as communicating negative information about the firm's future prospects. ${ }^{4}$

CE2 represents the firm's market-adjusted stock performance after the event period as measured by the cumulative excess return over the 200-day period from +41 to +241 . The measurement procedure is the same as described for CE1. For stock offerings that convey greater insiders' negative expectations about future prospects, the more negative stock price behavior observed at the time of the announcement will continue to occur as negative expectations are fully realized. If so, signaling models (Leland and Pyle, 1977; Ross, 1977) predict a positive coefficient for CE2.

IWT represents the shift in risk as measured by the pre-announcement standard deviation of return for days -220 to -21 minus the post-announcement standard deviation of return for days +41 to +240 . Intrasecurity wealth transfer models predict a negative coefficient. Stock for debt transactions that lower risk are expected to transfer wealth from stockholders to debtholders.

$\mathrm{COM}$ is a dummy variable representing primary $(\mathrm{COM}=0)$ versus combination offerings $(\mathrm{COM}=1)$. The Leland and Pyle (1977) signaling model predicts a negative coefficient. Investors are likely to suspect that insiders are the "current" or "principal" shareholders mentioned by news releases as engaged in secondary selling. A similar variable is tested by Masulis and Korwar (1986). They find a significant negative coefficient.

BAN is a dummy variable distinguishing bank debt reductions $(\mathrm{BAN}=0)$ from nonbank debt reductions $(\mathrm{BAN}=1)$. Bank debt signaling models hypothesize a positive coefficient. As discussed earlier, bank debt reductions should be accompanied by a greater negative signaling effect because the reduction can be linked to actions by bankers.

\section{B. Regression Findings}

Exhibit 4 reports OLS regression results. ${ }^{5}$ This study's regression results are similar if t statistics are corrected using White (1980) asymptotically consistent standard error estimates. Results are also robust for other alternative functional forms referred to in previous studies (Cornett and Travlos, 1989; Mikkelson and Partch, 1986). There is no evidence that the more extreme values for SHR, LEV, CE1, CE2, or IWT explain the findings.

Exhibit 4 includes six regression results for the total sample, the bank debt portfolio, and the nonbank debt portfolio. SHR and LEV are regressed separately in the reported results to avoid collinearity. The Pearson and Spearman rho values are above -0.65 for all tests. Thus, caution must be taken in interpreting results for LEV and SHR, because either can proxy for the other.

The regression results for the entire sample provide stronger support for the bank debt signaling effect than for other hypothesized effects. Both coefficients for BAN are significant at the 0.01 level indicating support for bank debt signaling models. The two coefficients for IWT are negative and significant at the 0.05 level. This finding lends support to agency models dealing with wealth transfers caused by risk shifting.

Mixed support is found for the Leland and Pyle (1977) propositions. The coefficient for COM is significant at the 0.01 level in one case and at the 0.05 level in the other, but the coefficients for SHR and CE2 are not significant at the 0.05 level. The insignificant coefficients for LEV, CE1, and CE2 do not support Ross (1977), although, the sign for each coefficient is in the direction predicted by Ross. The results for LEV are not consistent with Modigliani and Miller (1963).

Analysis of the regression results for the bank debt and nonbank debt reduction portfolios reported in Exhibit 4 can offer insight as to which of the competing models best explain the CARs for these two portfolios. The presence of signaling (based on changes in the magnitude of debt levels and on changes in the percentage of inside ownership) and intrasecurity wealth transfer effects is much more evident in the bank debt reduction portfolio tests, as indicated by both the sign and the magnitude of the coefficients. The coefficients for CE1, CE2, and IWT are noticeably different between portfolios. For the nonbank debt reduction test, the coefficient of CE2 is significant at the 0.05 level but opposite in sign to support a signaling effect. The significant negative coefficient for COM in the nonbank debt reduction test $(n=254)$ that includes SHR should be interpreted cautiously, as there are only 14 combination offers in the portfolio.

\footnotetext{
${ }^{4}$ Asquith and Mullins (1986) find a positive coefficient for CE1. Unlike this study, the purpose of their equity offerings involves more than just debt reduction.

${ }^{\mathbf{5}}$ OLS regression results are generally reported by prior event period regression studies (Asquith and Mullins, 19886; Dierkens, 1991; Finnerty, 1985; Masulis, 1983; Masulis and Korwar, 1986).
} 
Bank Debt Reduction Announcements and Negative Signaling / FM (1994), pp. 21-30 / Hull \& Moellenberndt

\section{EXHIBIT 4. Regression Results for 496 Common Stock Offerings that Reduce Bank Debt and Nonbank Debt, 1970-1988}

The regression model is: CAR $=b_{0}+b_{1}$ SHR $+b_{2}$ LEV $+b_{3}$ CE $1+b_{4}$ CE $2+b_{5}$ IWT $+b_{6}$ COM $+b_{7}$ BAN where

$\mathrm{CAR}=$ three-day cumulative abnormal return expressed in decimal form

SHR $=$ the number of planned new (primary) common shares divided by total outstanding common shares

$\mathrm{LEV}=$ the expected book value of retired debt divided by firm value (firm value is defined in Exhibit 1)

$\mathrm{CE} 1=$ cumulative excess return for days -220 to -21

$\mathrm{CE} 2=$ cumulative excess return for days +41 to +240

IWT $=$ stock return standard deviation for days -220 to -21 minus the standard deviation for days +41 to +240

$\mathrm{COM}=0$ if primary offering; $=1$ if combination offering

$\mathrm{BAN}=0$ bank debt reduction; $=1$ nonbank debt reduction

Columns for the seven independent variables report estimated coefficients with one-tailed $t$ statistics beneath the coefficients. The last column reports adjusted $r$-square values with $F$ values beneath the $r$-square values. Significance levels are indicated as follows: * denotes significance at the 0.01 level; $* *$ denotes significance at the 0.05 level.

\begin{tabular}{|c|c|c|c|c|c|c|c|c|}
\hline $\begin{array}{c}\text { Constant } \\
\mathrm{b}_{\odot}\end{array}$ & $\begin{array}{c}S H R \\
\mathrm{~b}_{1}\end{array}$ & $\begin{array}{r}\text { LEV } \\
\mathrm{b}_{2}\end{array}$ & $\begin{array}{c}C E 1 \\
\mathrm{~b}_{3}\end{array}$ & $\begin{array}{c}C E 2 \\
\mathrm{~b}_{4}\end{array}$ & $\begin{array}{r}I W T \\
b_{5}\end{array}$ & $\underset{b_{6}}{C O M}$ & $\begin{array}{c}B A N \\
\mathrm{~b}_{7}\end{array}$ & $\begin{array}{l}\text { Adj } R^{2} \\
\text { F-Value }\end{array}$ \\
\hline \multicolumn{9}{|c|}{ Total Sample $(n=496)$} \\
\hline-0.045 & $-\odot .004$ & & $-\odot .011$ & $\odot . \odot \odot \odot$ & -0.518 & -0.015 & 0.014 & 0.058 \\
\hline$-6.06 *$ & -0.24 & & -1.50 & $\odot .12$ & $-1.72 * *$ & $-2.32^{*}$ & $2.84^{*}$ & $6.03^{*}$ \\
\hline-0.042 & & 0.033 & -0.007 & $\odot .000$ & -0.515 & -0.014 & 0.013 & 0.060 \\
\hline$-5.62^{*}$ & & 1.12 & -1.44 & $\odot .06$ & $-1.72 * *$ & $-2.18 * *$ & $2.64^{\star}$ & $6.25^{\star}$ \\
\hline \multicolumn{9}{|c|}{ Bank Debt Portfolio $(n=242)$} \\
\hline-0.040 & -0.011 & & -0.026 & 0.010 & -0.733 & -0.015 & & $\odot .058$ \\
\hline$-4.49^{\star}$ & -0.48 & & $-2.59^{\star}$ & 1.25 & $-1.86^{* *}$ & $-2.02^{* *}$ & & $3.98^{*}$ \\
\hline$-\odot .0306$ & & 0.053 & -0.025 & $\odot .011$ & -0.751 & -0.015 & & 0.064 \\
\hline$-3.92^{*}$ & & 1.28 & $-2.61^{*}$ & 1.29 & $-1.92^{* *}$ & $-1.93^{* *}$ & & $4.28^{*}$ \\
\hline \multicolumn{9}{|c|}{ Nonbank Debt Portfolio ( $n=254)$} \\
\hline$-\odot .038$ & $-\odot .0 \odot 8$ & & $\odot .010$ & $-\odot .02 \odot$ & $-\odot .085$ & $-\odot .021$ & & $\odot .006$ \\
\hline$-2.92^{\star}$ & -0.28 & & $\odot .99$ & $-1.89 * *$ & -0.18 & $-1.63 * *$ & & 1.27 \\
\hline-0.036 & & 0.036 & 0.011 & -0.019 & -0.047 & -0.019 & & 0.008 \\
\hline$-2.78^{*}$ & & 0.82 & 1.08 & $-1.85^{* *}$ & -0.10 & -1.54 & & 1.39 \\
\hline
\end{tabular}

\section{Other Regression Results}

It is possible that the regression results for BAN reported in the total sample tests in the first two rows in Exhibit 4 are explained by the fact that private swaps are not found in the bank debt reduction portfolio. To explore this possibility, tests were first conducted with a dummy variable representing swaps ( $\mathrm{SWAP}=1$ ) versus nonswaps ( $\mathrm{SWAP}=0$ ). The coefficient for $\mathrm{SWAP}$ is insignificant, while the results for the other variables are unchanged. When tests are repeated excluding BAN, the variable SWAP is not quite significant at the 0.05 level.

Results of regression tests that exclude the 194 nonbank debt reductions that are swaps are also similar to the tests reported in the first two rows in Exhibit 4. Results of tests without the 60 nonbank debt reductions that are nonswaps are also similar, with two exceptions. First, the coefficient for BAN is no longer significant at the 0.01 level (but falls to near the 0.05 level). When SHR or LEV is omitted from the test, BAN is significant at the 0.01 level $(t=2.27)$. Second, the coefficient for CE1 becomes statistically significant at the 0.01 level $(t=-2.53)$ for both tests. These results indicate greater support for the debt level signaling model of Ross (1977) (than found when the 60 observations are included). Additionally, the results for BAN and other explanatory variables are unaltered if the regression tests are repeated with combination offerings or OTC observations deleted.

Tests were also conducted with a variable representing a firm's growth potential (GROW), as measured by the market value of common stock divided by book value of common stock. Although not statistically significant at the 0.05 level, a negative coefficient was found for all tests. This finding indicates that growth firms that issue equity to retire debt are more likely to produce a negative 
Bank Debt Reduction Announcements and Negative Signaling / FM (1994), pp. 21-30 / Hull \& Moellenberndt

market response (relative to no growth firms). This finding contrasts with the positive coefficient found by prior research, such as Dierkens (1991), where the purpose of the stock offering includes more than just debt reduction.

Finally, tests were repeated using two-day CARs instead of three-day CARs. Although we do not report it here, we find stronger support for bank debt signaling models when we considered two-day CARs. For these tests, the adjusted $r$-square and $F$-values reported in Exhibit 4 fall slightly.

\section{Summary}

Our study examines 242 NYSE/AMEX and OTC common stock offerings that reduce bank debt and 254 that retire nonbank debt. We find that bank debt reductions are associated with negative announcement period stock returns that are more than twice the magnitude of the negative returns associated with nonbank debt reductions. The differences in returns are statistically significant and hold regardless of the inclusion of private swaps, combination offerings, or OTC observations. The differences are also not dependent upon size considerations. The greater negative returns associated with bank debt reductions appear to result from the transmission of negative information beyond that posited by capital structure models previously cited in the literature to explain stock returns.

The regression tests support bank debt signaling models that predict that bankers play a unique role as transmitters of information in the capital markets. The tests also show that the greater negative market response to bank debt reduction announcements (compared to nonbank debt reduction announcements) may be attributable to greater signaling effects as hypothesized by Leland and Pyle (1977) and Ross (1977) and greater agency effects caused by shifts in risk that favor debtholders.

The findings are useful to managers making decisions about debt reductions. If executives are indifferent on reducing bank debt or nonbank debt, they should choose nonbank debt. If reducing bank debt is more preferable than reducing nonbank debt, they should try to explain the advantages of their bank debt reduction choice. Such advantages could include reducing interest payments, lowering bank-monitored costs, diversifying the company's sources of financing, or minimizing bank control of the firm's profit distribution.

The fact that bank debt reductions are not explained in news releases adds to the puzzle of debt reduction choices. It is possible that reasons we have not fully considered in our tests cause some adverse credit decisions. For example, bankers may force a debt reduction to achieve internal goals related to management of assets and liabilities, or managers may have no other debt reduction alternative. Whatever the reasons, the market appears a harsh judge of the bank debt reduction decision.

\section{References}

P. Asquith, and D. Mullins, Jr., 1986, "Equity Issues and Offering Dilution," Journal of Financial Economics, Vol. 15 (January-February), 61-89.

B. Bernanke, 1983, "Non-Monetary Effects of the Financial Crisis in the Propagation of the Great Depression," American Economic Review, Vol. 73 (June), 257-276.

S. Brown, and J. Warner, 1985, "Using Daily Stock Returns: The Case of Event Studies," Journal of Financial Economics, Vol. 14 (March), 3-31.

T. Copeland, and W. Lee, 1991, "Exchange Offers and Stock Swaps-New Evidence," Financial Management, Vol. 20 (Autumn) 34-48.

M. Cornett, and N. Travlos, 1989, "Information Effects Associated with Debt-for-Equity and Equity-for-Debt Exchange Offers," Journal of Finance, Vol. 44 (June), 451-468.

N. Dierkens, 1991, "Information Asymmetry and Equity Issues," Journal of Quantitative Analysis, Vol. 26 (June), 181-199.

E. Fama, 1985, "What's Different About Banks?" Journal of Monetary Economics, Vol. 15, 29-39.

J. Finnerty, 1985, "Stock-for-Debt Swaps and Shareholder Returns," Financial Management, Vol. 14 (Autumn), 5-17.

D. Galai, and R. Masulis, 1976, "The Option Pricing Model and the Risk Factor of Stock," Journal of Financial

Economics, Vol. 3 (January/March), 53-81.

J. Hand, 1989, "Did Firms Undertake Debt-Equity Swaps for an Accounting Paper Profit or True Financial Gain?" Accounting Review, Vol. 64 (October), 587-623.

C. James, 1987, "Some Evidence on the Uniqueness of Bank Loans," Journal of Financial Economics, Vol. 19

(December), 217-235.

M. Jensen, and W. Meckling, 1976, "Theory of the Firm: Managerial Behavior, Agency Costs and Ownership

Structure," Journal of Financial Economics, Vol. 3 (October), 305-360.

E. Kane, and B. Malkiel, 1965, "Deposit Variability, Bank-Portfolio Allocation and the Availability Doctrine," Quarterly Journal of Economics, Vol. 79 (February), 113-134. 
Bank Debt Reduction Announcements and Negative Signaling / FM (1994), pp. 21-30 / Hull \& Moellenberndt

J. Karpoff, and D. Lee, 1991, "Insider Trading before New Issue Announcements," Financial Management, Vol. 20 (Spring), 18-26.

H. Leland, and D. Pyle, 1977, "Informational Asymmetries, Financial Structure, and Financial Intermediation," Journal of Finance, Vol. 32 (May), 371-388.

S. Lummer, and J. McConnell, 1989, "Further Evidence on the Bank Lending Process and the Capital Market Response to Bank Loan Agreements," Journal of Financial Economics, Vol. 32 (November), 99-122.

R. Masulis, 1980, "The Effects of Capital Structure Change on Security Prices: A Study of Exchange Offers," Journal of Financial Economics, Vol. 8 (June), 139-178.

R. Masulis, 1983, "The Impact of Capital Structure Change on Firm Value: Some Estimates," Journal of Finance, Vol. 38 (March), 107-126.

R. Masulis, and A. Korwar, 1986, "Seasoned Equity Offerings: An Empirical Investigation," Journal of Financial Economics, Vol. 15 (January/February), 91-118.

W. Mikkelson, and M. Partch, 1986, "Valuation Effects of Security Offerings and the Issuance Process," Journal of Financial Economics, Vol. 15 (January/February), 31-60.

W. Mikkelson, and M. Partch, 1988, "Withdrawn Security Offerings," Journal of Financial and Quantitative Analysis, Vol. 23 (March), 119-133.

F. Modigliani, and M. Miller, 1963, "Corporate Income Taxes and the Cost of Capital: A Correction," American Economic Review, Vol. 53 (June), 433-443.

J. Peavy, and J. Scott, 1985, "The Effect of Stock-for-Debt Swaps on Security Returns," The Financial Review, Vol. 20 (November), 303-327.

J. Pinegar, and R. Lease, 1986, "The Impact of Preferred-for-Common Exchange Offers on Firm Value," Journal of Finance, Vol. 41 (September), 795-814.

R. Rogers, and J. Owers, 1985, "Equity for Debt Exchanges and Shareholder Wealth," Financial Management, Vol. 14 (Autumn), 18-26.

S. Ross, 1977, "The Determination of Financial Structure: The Incentive-Signaling Approach," Bell Journal of Economics, Vol. 8 (Spring), 23-40.

M. Scholes, and J. Williams, 1977, "Estimating Betas from Nonsynchronous Data," Journal of Financial Economics, Vol. 5 (December), 309-328.

H., White, 1980, "A Heteroskedasticity-Consistent Covariance Matrix Estimator and a Direct Test for Heteroskedasticity," Econometrica Vol. 48 (May), 817-838. 


\section{Executive Summary}

A firm's outstanding debt obligations can become burdensome for a number of reasons. The debt may cause investors to raise questions about the firm's ability to pay its creditors and remain solvent. The debt may be expensive relative to costs the firm would incur today in terms of either coupon rates or agency costs-such as debt covenants that prevent manager-agents from pursuing preferred investment opportunities or desired dividend payouts. Given such drawbacks, a financial manager could decide that reducing the firm's current debt level will benefit participants with a vested interest in the firm's future cash flows.

If a manager chooses to reduce debt, the immediate task is to accumulate cash for payment to debtholders. One way is to issue new common stock, a costly solution because stock offerings are typically accompanied by an adverse market reaction. A number of studies indicate the stock price falls 3 percent on average.

The negative reaction is understandable, given investor concerns about the issuance of overvalued stock. This is especially so if insiders are not public about their intent to maintain their ownership proportions-or, even worse, if the firm simultaneously announces a secondary offering by its "current owners." Particularly in the case of a stock offering that reduces debt, the overvaluation concern is exacerbated if market participants believe the announcement is motivated by concern about the risk of financial distress and the firm's ability to service current debt levels.

The overvaluation and financial distress concerns-along with dilution of earnings per share, issuance expenses, distribution of voting rights, agency considerations, lost tax shields-have been the subject of prior studies. However, the research has not analyzed whether the market responds differently to bank debt reductions than to nonbank debt reductions. This is surprising, given that bankers are privy to inside information and that bank debt reductions would be expected to convey negative inside banker information.

For about two out of three stock-for-debt announcements, the financial press specifies whether the debt reduction involves bank debt or nonbank debt. The former may be called simply "bank debt," "bank loans," or bank borrowings." Other announcements may be more descriptive, referring to bank debt as "term loan agreements" or "revolving credit agreements," and even specifying terms related to maturity and bank lending rates. When the financial press indicates that the debt being reduced is nonbank debt, the words "bond," "debenture," "long-term," or "public" are often used. Less frequently, nonbank debt may be described as "mortgage bonds," "lease obligations," or "equipment trust certificates."

It is important for several reasons to examine whether there are different market responses to bank debt reductions. First, from a practical perspective, information on any differences should be useful to financial managers making debt reduction decisions. If managers are able to reduce either type of debt, they could choose to reduce the one that avoids or minimizes any adverse market reaction. Second, input concerning the market response to bank debt announcements can be useful in guiding and shaping capital structure theories that influence the financial decision-making process.

Our study examines portfolios of 242 common stock offerings in which proceeds were used to reduce bank debt and 254 in which proceeds were used to reduce nonbank debt. For the stock offerings that reduce bank debt, there is a $-3.80 \%$ average abnormal announcement period stock return. This compares to only a $-1.86 \%$ average return for the other portfolio. Over two-thirds of this nearly 2 percentage point difference in market response occurs on the announcement day. The difference in market response to the two types of announcements is statistically significant and is not explained by outliers. This difference and the reported regression findings support bank debt signaling models that argue that bankers have access to inside information, and that it can be conveyed to the market in decisions on outstanding bank loans.

The findings raise questions about the hypothesized capital structure effects that currently guide financial management practices and strategies. For example, to what extent should financial managers be influenced by concerns the market may have about corporate tax shield and financial distress effects? To what degree should they be guided by market concerns that insiders may not be buying part of the new equity issue? The results of our study indicate that bank debt reduction effects are at least as important as other hypothesized capital structure effects. 